\title{
An In Vitro-Ex Vitro Micropropagation System for Hemp
}

\author{
Jessica D. Lubell-Brand ${ }^{1}$, Lauren E. Kurtz ${ }^{1}$, and Mark H. Brand ${ }^{1}$
}

\begin{abstract}
AdDitional Index wORDs. Cannabis sativa, retipping, tissue culture
SUMMARY. Hyperhydricity of shoots initiated in vitro, poor shoot extension, inability of shoot cultures to maintain good growth over an extended time, and unsuccessful ex vitro rooting have limited the development of a commercial scale micropropagation system for hemp (Cannabis sativa). We present a culture initiation method that prevents shoot hyperhydricity using vented-lid vessels with $0.2-\mu \mathrm{m}$ pores and medium containing agar at $1 \%(\mathrm{w} / \mathrm{v})$. To optimize shoot multiplication in vitro, a control medium (medium $A$ ) and four treatment media (medium B, C, D, and $E$ ), with varying inorganic nutrients and vitamins were tested. Control medium $A$ consisted of $1 \times$ Murashige and Skoog $(\mathrm{MS})$ with vitamins plus $3 \%(\mathrm{w} / \mathrm{v})$ sucrose, 0.5 $\mathrm{mg} \cdot \mathrm{L}^{-1}$ metatopolin, $0.1 \mathrm{mg} \cdot \mathrm{L}^{-1}$ gibberellic acid, and $0.8 \%$ agar $(\mathrm{w} / \mathrm{v})$ at $\mathrm{pH} 5.7$. The four treatment media differed from the control medium as follows: medium $B$, $2.5 \times$ MS with vitamins; medium $\mathrm{C}, 1 \times \mathrm{MS}$ with vitamins plus added mesos [calcium chloride (anhydrous), magnesium sulfate (anhydrous), and potassium phosphate (monobasic) nutrients]; medium $\mathrm{D}, \mathrm{I} \times \mathrm{MS}$ with vitamins plus added vitamins; and medium E, $1 \times$ MS with vitamins plus added mesos and vitamins. Medium $C$ and medium E produced more microcuttings than the control at 6 weeks after the initial subculture with shoot multiplication media and all other treatments at 9 and 12 weeks. Shoots grown on these two media displayed optimal extension and leaf lamina development; however, they exhibited slight chlorosis by 12 weeks after subculture with shoot multiplication media. In a separate experiment, medium $\mathrm{E}$ was supplemented with ammonium nitrate at $0,500,1000$, or $1500 \mathrm{mg} \cdot \mathrm{L}^{-1}$, and cultures grown with $500 \mathrm{mg} \cdot \mathrm{L}^{-1}$ produced the most microcuttings and exhibited the best combination of shoot extension and leaf lamina development. We provide a method of prerooting microshoots in vitro that has resulted in $75 \%$ to $100 \%$ rooting ex vitro in rockwool. Using 10 recently micropropagated plants, $\approx 300$ retip cuttings (cuttings taken from new shoots from recently micropropagated plants) were harvested over 10 weeks. The average weekly rooting was more than $90 \%$. Retipping can produce ninetimes as many plants in a similar amount of floor space as stem cuttings derived from traditional stock mother plants. The micropropagation/retipping method proposed can be a more efficient way to generate clonal liner plants for commercial-scale production.
\end{abstract}

$\mathrm{T}$ here is increased interest in the production of hemp (Cannabis sativa) because of its medicinal properties (Small, 2015). For commercial production purposes, hemp is propagated by seed or stem cuttings to take advantage of superior genotypes (Cervantes, 2015). Many indoor hemp production facilities propagate cultivars by taking stem cuttings from stock mother plants, which they must maintain (Bechtel,

Received for publication 16 Dec. 2020. Accepted for publication 13 Feb. 2021.

Published online 19 March 2021.

${ }^{1}$ Department of Plant Science and Landscape Architecture, University of Connecticut, 1376 Storrs Road, Unit-4067, Storrs, CT 06269

J.D.L.-B. is the corresponding author. E-mail: Jessica. lubell@uconn.edu.

This is an open access article distributed under the $\mathrm{CC}$ BY-NC-ND license (https://creativecommons.org/ licenses/by-nc-nd/4.0/).

https://doi.org/10.21273/HORTTECH04779-20
2019). Mother plants are large (10gal container size) and require a significant amount of grow space to provide enough cuttings to meet production quotas. Growers must maintain mother plants in triplicate, with each replicate grown in a separate area of the facility, to reduce the risk of losing valuable cultivars to sudden disease outbreaks. Mother plants lose vigor because of the serial removal of shoots for cuttings, and they must be replaced every 6 months. Additionally, over time, mother plants accumulate insects and diseases, thus limiting their useful life as donors of cuttings. Overall, this propagation process is labor-intensive and inefficient. Hemp growers are interested in micropropagation as an alternative method of generating clones for commercial production (Rosslee, 2020).

Micropropagation provides unique benefits to growers and has several advantages over traditional plant cloning systems. These include the production of a large number of genetically clonal plants, uniform plants with enhanced vigor, diseasefree plants, and preservation of maternal germ lines (Hartmann et al., 2002). Micropropagation also requires substantially fewer mother plants to be maintained compared with traditional stem cutting propagation, and in vitro cultures can be stored for longer in a smaller area than mother plants.

There are few published reports of hemp micropropagation. Wang et al. (2009) evaluated the effects of growth regulator additions to Murashige and Skoog (MS) medium on in vitro shoot multiplication and rooting of hemp cultures started from seed. Using nodal stem segments and MS medium, Lata et al. (2009) similarly tested rates of three growth regulators alone and in combination with gibberellic acid $\left(\mathrm{GA}_{3}\right)$ on shoot multiplication. Lata et al. (2016) published a protocol refinement of their previous work (Lata et al., 2009) and introduced the growth regulator meta-topolin (MT), which was found to be superior to thidiazuron (TDZ) for in vitro shoot multiplication. Unfortunately, these published protocols have not translated well to large-scale micropropagation of clones necessary for commercial production. Noted shortcomings of published micropropagation methods

\begin{tabular}{llll}
\hline $\begin{array}{l}\text { Units } \\
\begin{array}{l}\text { To convert U.S. to SI, } \\
\text { multiply by }\end{array}\end{array}$ & U.S. unit & SI unit & $\begin{array}{l}\text { To convert SI to U.S., } \\
\text { multiply by }\end{array}$ \\
\hline 29.5735 & $\mathrm{fl} \mathrm{oz}$ & $\mathrm{mL}$ & 0.0338 \\
0.0929 & $\mathrm{ft}^{2}$ & $\mathrm{~m}^{2}$ & 10.7639 \\
3.7854 & gal & $\mathrm{L}$ & 0.2642 \\
2.54 & inch(es) & $\mathrm{cm}$ & 0.3937 \\
25.4 & inch(es) & $\mathrm{mm}$ & 0.0394 \\
1 & micron $(\mathrm{s})$ & $\mu \mathrm{m}$ & 1 \\
28.3495 & $\mathrm{Oz}$ & $\mathrm{g}$ & 0.0353 \\
1 & $\mathrm{ppm}$ & $\mathrm{mg} \cdot \mathrm{L}^{-1}$ & 1 \\
$\left({ }^{\circ} \mathrm{F}-32\right) \div 1.8$ & ${ }^{\circ} \mathrm{F}$ & ${ }^{\circ} \mathrm{C}$ & $\left({ }^{\circ} \mathrm{C} \times 1.8\right)+32$
\end{tabular}


Table 1. Various Murashige and Skoog (MS)-based media formulations for initiation and shoot multiplication of hemp.

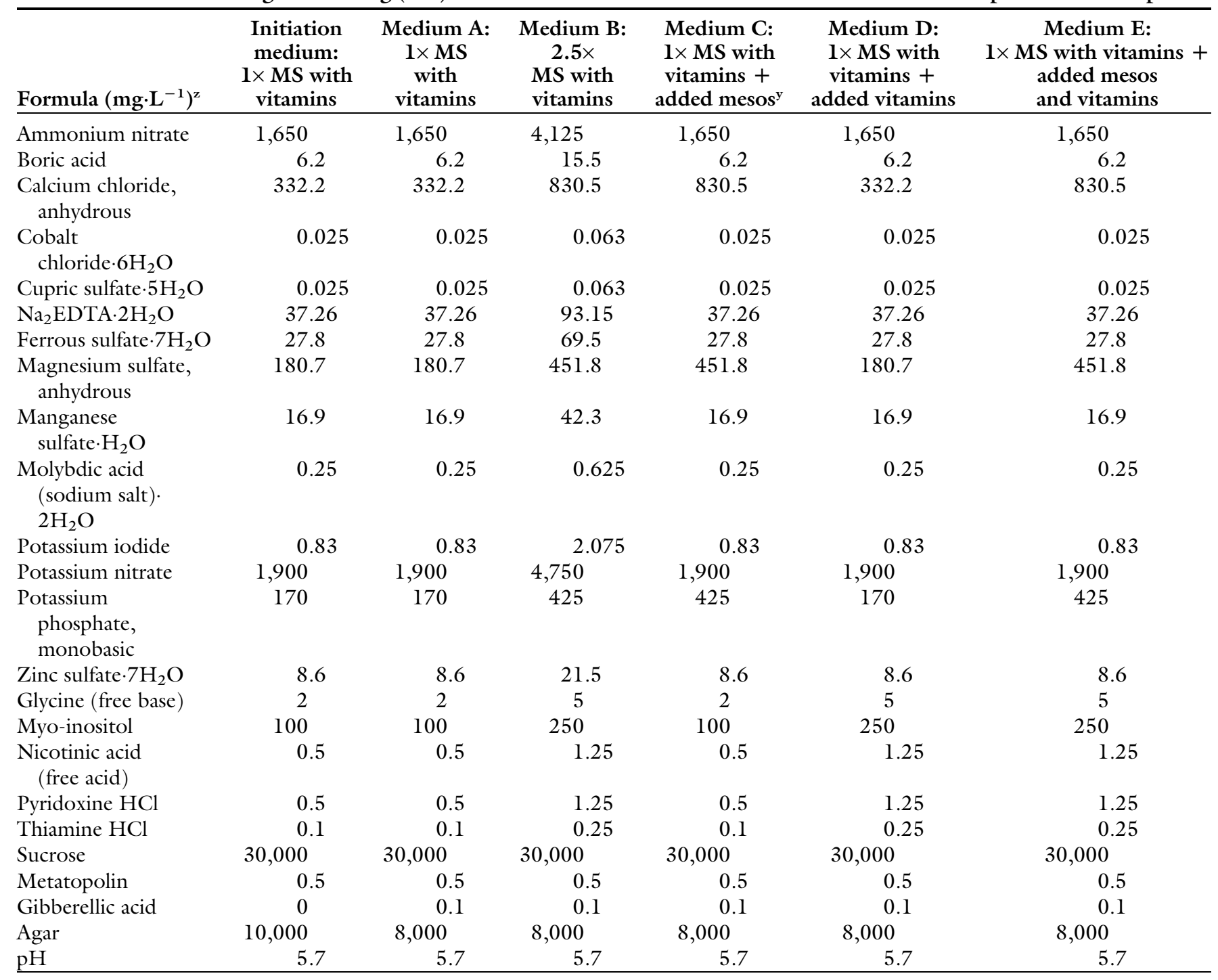

${ }^{\mathrm{z}} \mathrm{l} \mathrm{mg} \cdot \mathrm{L}^{-1}=1 \mathrm{ppm}$.

${ }^{\mathrm{y}}$ Mesos components include the calcium chloride (anhydrous), magnesium sulfate (anhydrous), and potassium phosphate (monobasic) nutrients.

include development of hyperhydricity during establishment of shoots in vitro, lack of consistent shoot elongation in culture, and inability of shoot cultures to maintain quality growth for an extended period of time (Monthony et al., 2021).

Microshoots from in vitro cultures are miniaturized, have altered physiology, and root easily (Hartmann et al., 2002). Nursery producers use a process called retipping to take advantage of and extend the period of time that micropropagated plants retain this miniaturized physiology so that more cuttings can be rooted (Keith and Brand, 1995). Retipping is the repeated harvesting of new shoots from recently micropropagated plants. The retipping process stimulates shoot growth from latent buds originating from the region of the stem that was miniaturized in culture. Retipping is routinely used to substantially increase the yield of propagules for crops such as rhododendron (Rhododendron sp.), mountain laurel (Kalmia latifolia), and lilac (Syringa vulgaris).

The objective of this work was to enhance hemp micropropagation by reducing hyperhydricity, improving in vitro shoot extension and performance through adjustment of the media nutrient content, and developing a method of ex vitro rooting. An additional objective was to evaluate retipping of recently micropropagated plants as a method of obtaining large quantities of clones for commercialscale hemp production.

\section{Materials and methods}

Plant material. The hemp cultivars Wife (US Hempcare, Niantic, CT) and Dinamed CBD (Dinafem seeds, San Sebastian, Spain) were used. 'Wife' was used for all studies and 'Dinamed CBD' was used for the retipping study only. Cultivars were maintained as 2 -gal stock plants in a greenhouse with set points of 21/ $17^{\circ} \mathrm{C}$ day/night temperatures under long-day (18-h) conditions provided by $600-\mathrm{W}$ high-pressure sodium (HPS) lamps (Phantom HPS 600W; 
Hydrofarm, Petaluma, CA) to maintain vegetative growth.

IN VITRO SHOOT INITIATION. To initiate shoots in vitro, $4-\mathrm{cm}$-long stem tips were collected from stock plants. After leaves were removed, stems were disinfected by immersion in a solution of $0.54 \%(\mathrm{w} / \mathrm{v})$ sodium hypochlorite and $0.1 \%$ surfactant (Tween 20; Croda Intl., Snaith, UK) for $15 \mathrm{~min}$ with intermittent agitation by hand, followed by rinsing in sterile distilled water. Then, stems were aseptically trimmed to remove damaged tissue and cultured in boxes (GA-7; Magenta, Lockport, IL) with vented lids featuring a vent with a diameter of $10 \mathrm{~mm}$ and pore size of $0.2 \mu \mathrm{m}$ (Caisson Laboratories, Smithfield, UT) and containing $45 \mathrm{~mL}$ of medium. Explants were trimmed to $\approx 2$-cm-long segments and four explants were placed per box. The initiation medium (Table 1) was MS with vitamins (Murashige and Skoog, $1962)$ plus $3 \%(\mathrm{w} / \mathrm{v})$ sucrose, 0.5 $\mathrm{mg} \cdot \mathrm{L}^{-1}$ metatopolin (MT), and $1.0 \%(\mathrm{w} / \mathrm{v})$ agar (Millipore Sigma, St. Louis, MO) at $\mathrm{pH}$ 5.7. After 3 weeks, sterile shoots were subcultured with the same medium and maintained for another 3 weeks, at which time they were subcultured with shoot multiplication medium. Cultures were maintained in a growth chamber (Percival, Perry, IA) at $25^{\circ} \mathrm{C}$ with an 18 -h photoperiod provided by cool white fluorescent lamps at an intensity of 40 $\mu \mathrm{mol} \cdot \mathrm{m}^{-2} \cdot \mathrm{s}^{-1}$.

IN VITRO SHOOT MULTIPLICATION. Two studies were conducted to opti-

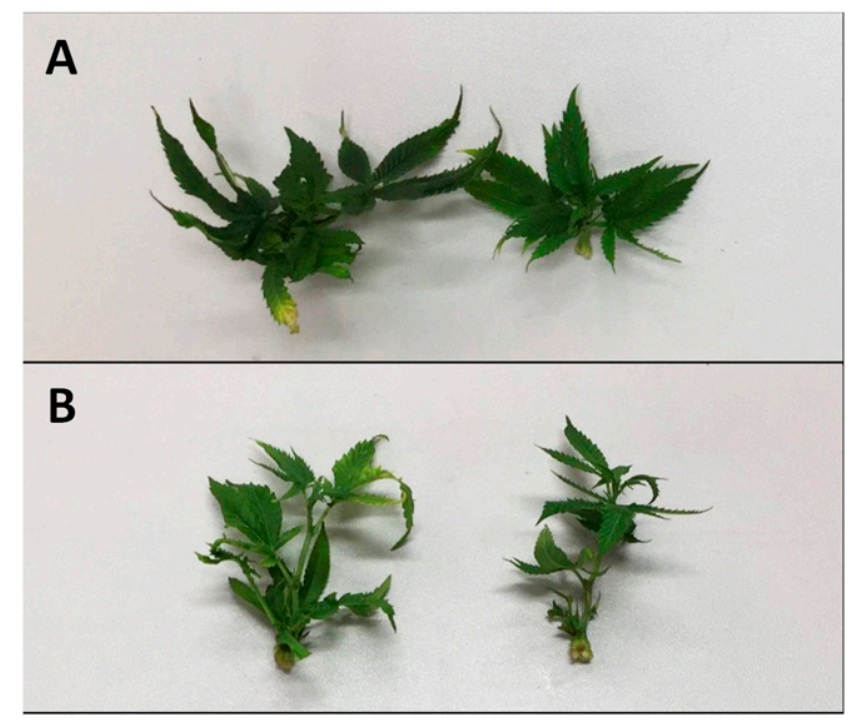

Fig. 1. Microshoots of hemp cultivar Dinamed CBD (A) at the end of the 6-week shoot initiation step and (B) after 3 additional weeks on initiation medium containing $0.1 \mathrm{mg} \cdot \mathrm{L}^{-1}$ gibberellic acid and $0.8 \%$ agar. $1 \mathrm{mg} \cdot \mathrm{L}^{-1}=1 \mathrm{ppm}$.

mize the nutrient composition of MS medium for in vitro shoot growth and performance. For these studies, in vitro shoots were initiated as described. The first shoot multiplication study evaluated the mesos components of MS, which included the calcium chloride (anhydrous), magnesium sulfate (anhydrous), and potassium phosphate (monobasic) nutrients. The control medium for this study was me$\operatorname{dium} \mathrm{A}$, which consisted of $\mathrm{l} \times \mathrm{MS}$ with vitamins plus $3 \%(\mathrm{w} / \mathrm{v})$ sucrose, 0.5 $\mathrm{mg} \cdot \mathrm{L}^{-1} \mathrm{MT}, 0.1 \mathrm{mg} \cdot \mathrm{L}^{-1} \quad \mathrm{GA}_{3}$, and $0.8 \%$ agar $(\mathrm{w} / \mathrm{v})$ at $\mathrm{pH} 5.7$ (Table $\mathrm{l})$. In addition to control medium $\mathrm{A}$, there were four other treatment media (formulations provided in Table 1 ): medium $\mathrm{B}, 2.5 \times \mathrm{MS}$ with vitamins; medium $\mathrm{C}$, $\mathrm{I} \times \mathrm{MS}$ with vitamins plus added mesos; medium $\mathrm{D}, \mathrm{I} \times \mathrm{MS}$ with vitamins plus added vitamins; and medium E, $1 \times$ MS with vitamins plus added mesos and vitamins. The second shoot multiplication study evaluated the addition of 0 , 500,1000 , or $1500 \mathrm{mg} \cdot \mathrm{L}^{-1}$ ammonium nitrate $\left(\mathrm{NH}_{4} \mathrm{NO}_{3}\right)$ to medium $\mathrm{E}$.

For both studies, the experimental unit was a box. At each subculture, four microcuttings were placed per box. There were 10 and 8 boxes per treatment for the mesos and $\mathrm{NH}_{4}{ }^{-}$ $\mathrm{NO}_{3}$ studies, respectively. For each study, experimental units were arranged in a completely random design. Cultures were subcultured every 3 weeks and maintained as described for in vitro shoot initiation. At each subculture, shoot extension and leaf lamina development were visually assessed by the lead author. Data were collected at 6,9 , and 12 weeks after shoots were initially subcultured with shoot multiplication media. For the mesos study, the numbers of $\approx 2-\mathrm{cm}$

Table 2. Number of 'Wife' hemp apical and two-node nonapical microcuttings per box subcultured on various modified Murashige and Skoog (MS) shoot multiplication media every 3 weeks during the first 12 weeks.

\begin{tabular}{lcc}
\hline & \multicolumn{2}{c}{$\begin{array}{c}\text { Apical and two-node nonapical microcuttings } \\
\text { (no./box) }\end{array}$} \\
\cline { 2 - 3 } Treatment medium $^{z}$ & 6 weeks & 9 weeks \\
\hline Medium A: $1 \times$ MS with vitamins (control) & $4.9 \mathrm{c}^{\mathrm{y}}$ & $4.1 \mathrm{~b}$ \\
Medium B: $2.5 \times$ MS with vitamins & $5.1 \mathrm{c}$ & $4.2 \mathrm{~b}$ \\
Medium C: $1 \times$ MS with vitamins + added mesos & $2.9 \mathrm{c}$ & $7.1 \mathrm{a}$ \\
Medium D: $1 \times$ MS with vitamins + added vitamins & $6.4 \mathrm{a}$ & $4.1 \mathrm{~b}$ \\
Medium E: $1 \times$ MS with vitamins + added mesos and vitamins & $6.0 \mathrm{a}$ & $6.6 \mathrm{~b}$ \\
\hline
\end{tabular}

${ }^{2}$ All media contained $3 \%(\mathrm{w} / \mathrm{v})$ sucrose, $0.5 \mathrm{mg} \cdot \mathrm{L}^{-1}$ metatopolin, $0.1 \mathrm{mg} \cdot \mathrm{L}^{-1}$ gibberellic acid, and $0.8 \%$ agar $(\mathrm{w} / \mathrm{v})$ at $\mathrm{pH} 5.7 .1 \mathrm{mg} \cdot \mathrm{L}^{-1}=1 \mathrm{ppm}$.

${ }^{\mathrm{y}}$ Mean separation within columns indicated by different letters according to Fisher's least significant difference test at $P \leq 0.05(\mathrm{n}=10)$.

${ }^{\mathrm{x}}$ Mesos components include the calcium chloride (anhydrous), magnesium sulfate (anhydrous), and potassium phosphate (monobasic) nutrients 


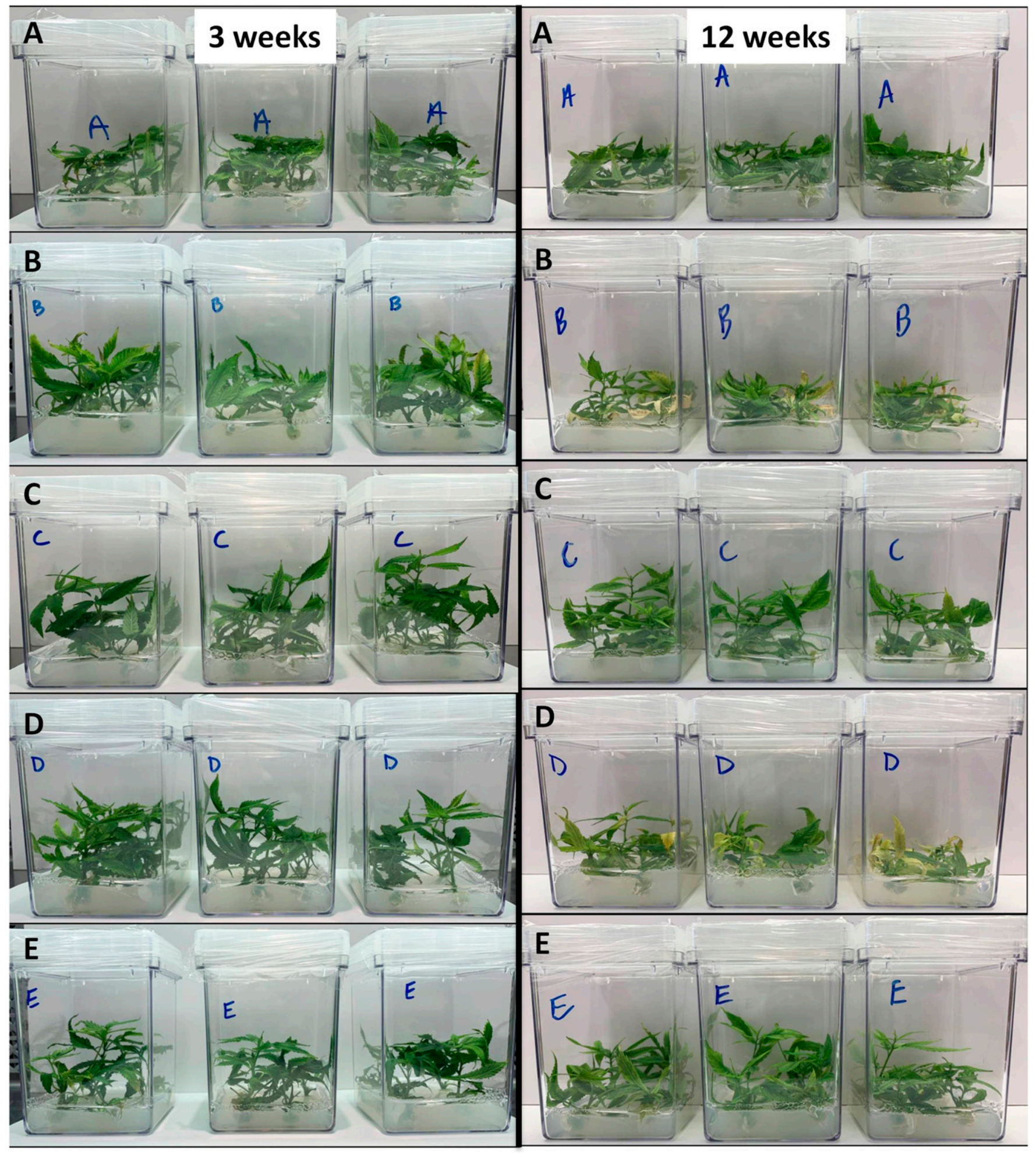

Fig. 2. In vitro cultures of hemp cultivar Wife after 3 weeks and 12 weeks of growth on experimental shoot multiplication media: (A) control medium A, $1 \times$ Murashige and Skoog (MS) medium with vitamins; (B) medium B, 2.5 $\times$ MS with vitamins; (C) medium C, $1 \times$ MS with vitamins plus added mesos; (D) medium D, $1 \times$ MS with vitamins plus added vitamins; and (E) medium $\mathrm{E}, \mathrm{l} \times \mathrm{MS}$ with vitamins plus added mesos and vitamins.

apical and two-node nonapical microcuttings per experimental unit were recorded. For the $\mathrm{NH}_{4} \mathrm{NO}_{3}$ study, the number of $\approx 2$-cm apical microcuttings per experimental unit was recorded. Data were subjected to an analysis of variance (PROC GLM) and mean separation with Fisher's least significant difference test $(P \leq 0.05)$ using SAS (version 9.4; SAS Institute, Cary, NC). Microcutting ROOTING AND acclimation. Microshoots were 
prerooted in vitro using MS with vitamins plus $3 \%(\mathrm{w} / \mathrm{v})$ sucrose, 1 $\mathrm{mg} \cdot \mathrm{L}^{-1}$ indole-3-butyric acid (IBA), and $0.8 \%$ agar $(\mathrm{w} / \mathrm{v})$ at $\mathrm{pH} 5.7$; boxes with vented lids were used. For prerooting, 8 to 10 microshoots were placed per box and cultures were maintained as described for in vitro shoot initiation. After $14 \mathrm{~d}$, microshoots had formed visible white root initials $(\approx 1 \mathrm{~mm})$ and were transferred ex vitro to 1 -inch rockwool cubes with preformed holes, set in 96-plug trays, and covered with clear plastic propagation domes to maintain humidity. Domed trays were maintained with 18-h photoperiods provided by cool white fluorescent lamps at an intensity of $30 \mu \mathrm{mol} \cdot \mathrm{m}^{-2} \cdot \mathrm{s}^{-1}$. Microcuttings rooted at $21 \mathrm{~d}$ and initiated new shoot growth. Rooted microcuttings were acclimated to greenhouse conditions by gradually decreasing atmospheric relative humidity around the microcuttings and gradually increasing light levels. This was accomplished by melting 30 holes (diameter, $0.5 \mathrm{~cm}$ ) in the domes and, 4 d later, melting 30 more holes in the domes. After $4 \mathrm{~d}$ with 60 holes in the domes, rooted microcuttings were potted in $307-\mathrm{mL}$ containers filled with a peatmoss-based potting mix (Promix BK25; Premier Tech Horticulture, Quakertown, PA). Plants were top-dressed with $15 \mathrm{~N}-$ $3.9 \mathrm{P}-10 \mathrm{~K}$ controlled-release fertilizer (Osmocote Plus 5- to 6-month formulation; Everris NA, Dublin, $\mathrm{OH})$ at $2.5 \mathrm{~g}$ per container. Potted plants were placed in the greenhouse with an 18-h photoperiod under $50 \%$ shade for $5 \mathrm{~d}$ before they were exposed to full light greenhouse conditions. Plants received a $20 \mathrm{~N}-8.7 \mathrm{P}-$ $16.6 \mathrm{~K}$ soluble fertilizer (Peters; Scotts, Marysville, $\mathrm{OH}$ ) providing 100 ppm nitrogen $(\mathrm{N})$ at every irrigation, which occurred as needed.

Retipping. For each of the three experimental time replications of retipping, 10 recently potted micropropagated plants were used. Plants were potted $10 \mathrm{~d}$ before taking the first retip cuttings, and plants were placed pot-to-pot on a greenhouse bench. The first two experimental time replications with 'Dinamed CBD' were initiated in July and Aug. 2019, and the third experimental time replication with 'Wife' was initiated in Apr. 2020. Retip cuttings with lengths of 5 to $8 \mathrm{~cm}$ were taken every week for 10 consecutive weeks. Cuttings were treated with talc-based IBA at 1000 ppm (Hormodin \#1; OHP, Mainland, PA) and stuck in l-inch rockwool cubes. Rockwool cubes were set in 96-plug trays in a staggered plug cell arrangement and covered with clear plastic propagation domes to maintain humidity. Before sticking the cuttings, a hole with a diameter of $\approx 3 \mathrm{~mm}$ was bored into rockwool cubes using a forceps, which prevented damaging the stem upon sticking. Retip cuttings were rooted and acclimated as described for microcuttings. The percent rooting of retip cuttings for each sticking date was recorded at $28 \mathrm{~d}$ after sticking.

\section{Results and discussion}

Lata et al. (2016) proposed a one-step in vitro propagation protocol using MS medium containing $3 \%(\mathrm{w} / \mathrm{v})$ sucrose, $0.5 \mathrm{mg} \cdot \mathrm{L}^{-1} \mathrm{MT}$, $0.8 \%(\mathrm{w} / \mathrm{v})$ agar, and $500 \mathrm{mg} \cdot \mathrm{L}^{-1}$ activated charcoal at $\mathrm{pH} 5.7$ in glass culture vessels with nonvented caps. We improved this protocol by adjusting the culture vessel to boxes with vented lids and changing the medium components for the shoot initiation and shoot multiplication steps. For shoot initiation, the amount of agar was increased; for shoot multiplication, the amounts of mesos components and $\mathrm{NH}_{4} \mathrm{NO}_{3}$ were adjusted and $\mathrm{GA}_{3}$ was added. Activated charcoal, used by Lata et al. (2016), was not included in our medium at any step. If care is used to remove all unfurled leaves down to the smallest leaves spread from the shoot apical meristem, then contamination rates can be reduced to close to $0 \%$. Low contamination rates with hemp shoot initiation may be attributable to the rapid shoot growth of greenhouse hemp plants that do not allow shoot tips to accumulate high microbial loads.

Using the method of Lata et al. (2016), shoots were hyperhydric and developed leaves that were light green in color, thick, translucent, and brittle. Possible causes of hyperhydricity are excessive humidity and/or high ethylene levels in vitro (Ivanova and Van Staden, 2009; Kevers et al., 1984). The physiological abnormalities caused by hyperhydricity are a serious problem for micropropagation and can result in up to $90 \%$ multiplication losses (Nairn et al., 1995). We were able to eliminate the development of hyperhydric shoots in vitro by using vessels with vented lids and a 6-week initiation step with medium containing increased agar $(1 \% \mathrm{w} / \mathrm{v})$. The use of vented lids and/or higher agar content effectively reduced hyperhydricity and improved the growth of cultures for aloe (Aloe vera), carnation (Dianthus caryphyllus), jones' cycladenia (Cycladenia bumilis var. jonesii), passion fruit (Passiflora edulis f. favicarpa), serviceberry (Amelanchier arborea), and other plants (Brand 1993; Ivanova and Van Staden, 2009; Majada et al., 1998; Pence et al., 2020; Trevisan and Mendes, 2005). By potentially reducing the relative humidity within the vessel using vented lids and the $\psi_{S}$ of the medium using more agar, shoots may have accumulated less water. Additionally, vented lids may have allowed for ethylene to leave the vessel

Table 3. Number of 'Wife' hemp apical microcuttings per box subcultured every 3 weeks during the first 12 weeks on shoot multiplication media $\mathrm{E}[1 \times$

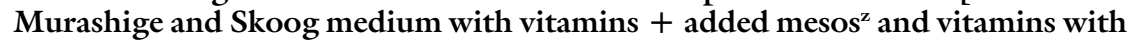
$3 \%(\mathrm{w} / \mathrm{v})$ sucrose, $0.5 \mathrm{mg} \cdot \mathrm{L}^{-1}$ metatopolin, $0.1 \mathrm{mg} \cdot \mathrm{L}^{-1}$ gibberellic acid, and $0.8 \%$ agar $(\mathrm{w} / \mathrm{v})$ at $\mathrm{pH} 5.7$ ] with additional ammonium nitrate $\left(\mathrm{NH}_{4} \mathrm{NO}_{3}\right)$ at 0 , 500,1000 , or $1500 \mathrm{mg} \cdot \mathrm{L}^{-1}$.

\begin{tabular}{llll}
\hline & \multicolumn{3}{c}{ Apical microcuttings (no./box) } \\
\cline { 2 - 4 } $\mathrm{NH}_{\mathbf{4}} \mathrm{NO}_{\mathbf{3}}\left(\mathbf{m g} \cdot \mathbf{L}^{-1}\right)^{\mathbf{y}}$ & $\mathbf{6}$ weeks & 9 weeks & $\mathbf{1 2}$ weeks \\
\hline 0 & $6.8 \mathrm{~b}^{\mathrm{x}}$ & $7.3 \mathrm{a}$ & $5.2 \mathrm{~b}$ \\
500 & $8.8 \mathrm{a}$ & $8.4 \mathrm{a}$ & $6.7 \mathrm{a}$ \\
1000 & $6.7 \mathrm{~b}$ & $5.1 \mathrm{~b}$ & $5.0 \mathrm{~b}$ \\
1500 & $6.6 \mathrm{~b}$ & $6.2 \mathrm{~b}$ & $5.0 \mathrm{~b}$ \\
\hline
\end{tabular}

${ }^{\mathrm{z}}$ Mesos components include the calcium chloride (anhydrous), magnesium sulfate (anhydrous), and potassium phosphate (monobasic) nutrients.

${ }^{\mathrm{y}} \mathrm{l} \mathrm{mg} \cdot \mathrm{L}^{-1}=1 \mathrm{ppm}$

${ }^{\mathrm{x}}$ Mean separation within columns indicated by different letters according to Fisher's least significant difference test at $P \leq 0.05(\mathrm{n}=8)$ 
rather than accumulate in vitro. At the end of the 6-week initiation step, shoots were not hyperhydric and had produced healthy, dark green leaves with expanded lamina, but the stems were not elongated (Fig. 1A). Preliminary studies performed to enhance shoot elongation tested concentrations of filter-sterilized $\mathrm{GA}_{3}$ from 0.05 to $0.9 \mathrm{mg} \cdot \mathrm{L}^{-1}$ (data not shown). It was observed that $0.1 \mathrm{mg} \cdot \mathrm{L}^{-1} \mathrm{GA}_{3}$ enhanced stem elongation (Fig. 1B) and that rates of $\mathrm{GA}_{3}$ greater than 0.1 $\mathrm{mg} \cdot \mathrm{L}^{-1}$ resulted in shoot tip collapse and necrosis.

Shoots grown on a multiplication medium modified from our initiation medium to contain $0.1 \mathrm{mg} \cdot \mathrm{L}^{-1} \mathrm{GA}_{3}$ and $0.8 \%$ agar improved the performance we observed using the medium reported by Lata et al. (2016), but it still demonstrated a reduction in performance over two subculture cycles. Cultures developed chlorosis and had less vigor, and multiplication rates declined. Commercial hemp producers conducting tissue culture tests have also experienced declines in shoot quality as cultures age during the short term. The observed decline of cultures was an indication that the shoot multiplication medium nutrients were not optimal for growth. Several plants, including gerbera (Gerbera bybrida), hazelnut (Corylus avellana), pear (Pyrus sp.), red raspberry (Rubus idaeus), and stevia (Stevia rebaudiana), have benefited from adjustments to the mesos nutrients and/or $\mathrm{NH}_{4} \mathrm{NO}_{3}$ of $\mathrm{MS}$ medium (Hand et al., 2014; Niedz et al., 2014; Poothong and Reed, 2015; Poothong et al., 2017, 2018; Wada et al., 2013).

Medium C and medium E produced the greatest number of usable microcuttings (Table 2). Cultures grown on these media (Fig. 2C and $\mathrm{E})$ were observed to be greener than those grown on medium $B$ and medium D (Fig. 2B and D). Shoots on medium $\mathrm{C}$ and medium $\mathrm{E}$ were observed to have better extension and leaf lamina development compared with the control medium $A$ at 12 weeks after the first subculture with shoot multiplication media (Fig. 2A, $\mathrm{C}$, and $\mathrm{E}$ ). The numbers of microcuttings were 1.5-times greater for medium $\mathrm{C}$ and medium $\mathrm{E}$ than the control at 12 weeks after the first subculture (Table 2 ). For medium C and medium $\mathrm{E}$, the numbers of microcuttings produced at 6,9 , and 12 weeks after the first subculture were the same or increased slightly. For medium B and medium D, the numbers of microcuttings produced decreased from 6 to 12 weeks after first subculture. Medium E supplemented with $500 \mathrm{mg} \cdot \mathrm{L}^{-1} \mathrm{NH}_{4} \mathrm{NO}_{3}$ produced more usable microcuttings than medium E and medium E supplemented with higher rates of $\mathrm{NH}_{4}$ $\mathrm{NO}_{3}$ (Table 3 ). Shoots produced on medium E with $500 \mathrm{mg} \cdot \mathrm{L}^{-1} \mathrm{NH}_{4}{ }^{-}$ $\mathrm{NO}_{3}$ exhibited the best combination of shoot extension and leaf lamina development (Fig. 3B), which is necessary for good rooting and acclimation to ex vitro conditions. We conclude that using this modified shoot multiplication medium, which contains added mesos and vitamins plus $500 \mathrm{mg} \cdot \mathrm{L}^{-1} \quad \mathrm{NH}_{4} \mathrm{NO}_{3}$, a $2 \times$ shoot multiplication rate can be achieved for hemp and maintained over a minimum of 12 weeks after the initiation step. Cultivars of pear and red raspberry similarly benefitted from additions of $\geq 2.5 \times$ mesos
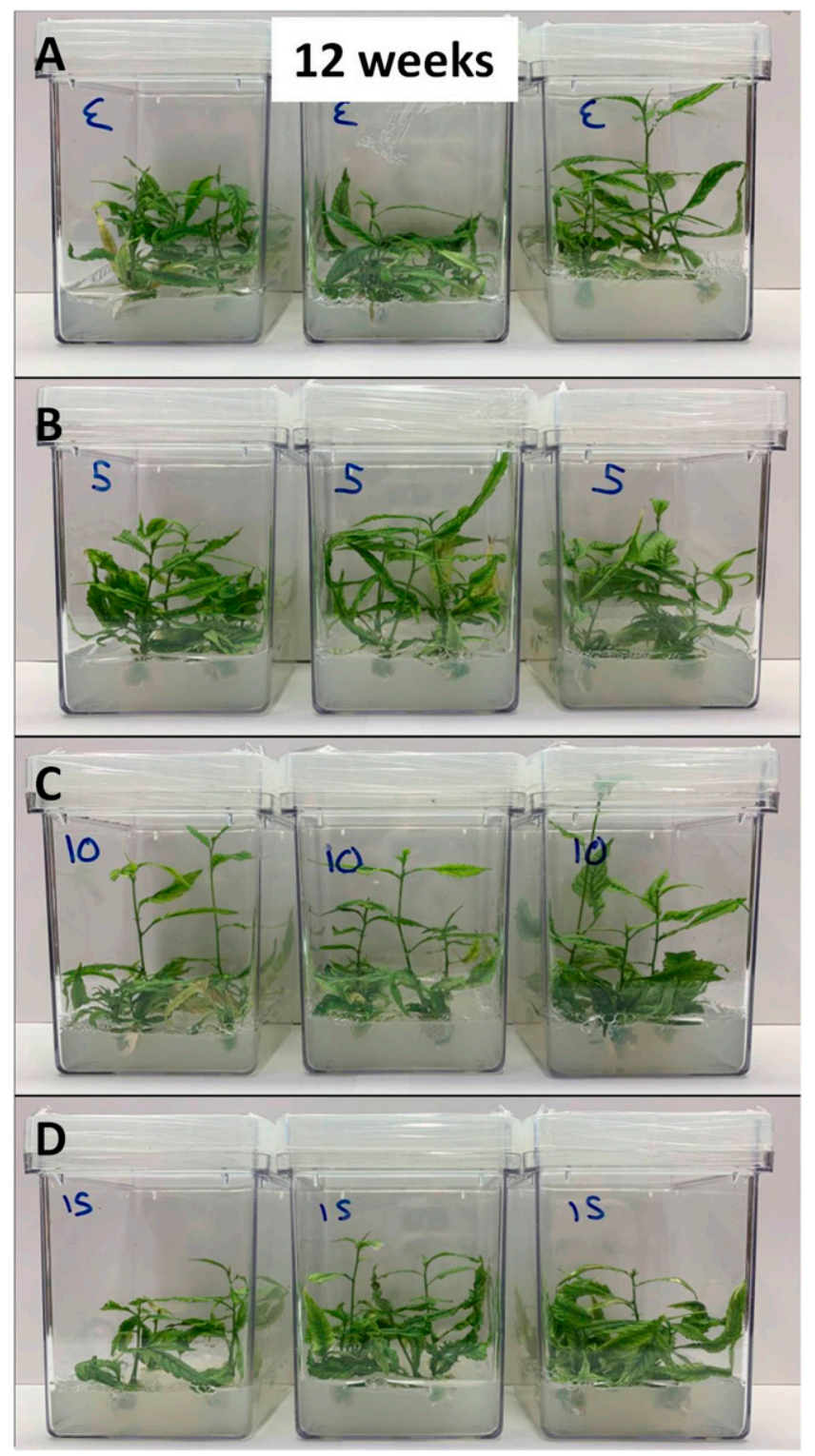

Fig. 3. In vitro cultures of hemp cultivar Wife after 12 weeks of growth on medium E comprising $1 \times$ Murashige and Skoog (MS) medium with vitamins plus added mesos and vitamins plus $3 \%(\mathrm{w} / \mathrm{v})$ sucrose, $0.5 \mathrm{mg} \cdot \mathrm{L}^{-1}$ metatopolin, $0.1 \mathrm{mg} \cdot \mathrm{L}^{-1}$ gibberellic acid, and $0.8 \%$ agar $(\mathrm{w} / \mathrm{v})$ at $\mathrm{pH} 5.7$ and supplemented with ammonium nitrate at: (A) $0 \mathrm{mg} \cdot \mathrm{L}^{-1}$; (B) $500 \mathrm{mg} \cdot \mathrm{L}^{-1}$; (C) $1000 \mathrm{mg} \cdot \mathrm{L}^{-1}$; and (D) $1500 \mathrm{mg} \cdot \mathrm{L}^{-1} \cdot 1 \mathrm{mg} \cdot \mathrm{L}^{-1}=1 \mathrm{ppm}$. 
(Poothong and Reed, 2015; Wada et al., 2013). Other plants have benefited from higher amounts of $\mathrm{N}$ salts, such as stevia, which preferred $3 \times \mathrm{N}$ (Poothong et al., 2018).

In vitro rooting of hemp microcuttings can be accomplished, but it is not practical for commercial production purposes (Lata et al., 2016). Growers have reported that rooting microcuttings ex vitro in humidity vessels with peat-based medium is largely unsuccessful. Our method of prerooting microcuttings in vitro followed by rooting ex vitro in rockwool has proven to be highly successful
(Fig. 4). For five replications of 'Dinamed CBD' microcuttings ranging from 18 to 56 , we achieved rooting of $100 \%(\mathrm{n}=18), 81 \%(\mathrm{n}=17)$, $75 \%(\mathrm{n}=52), 84 \%(\mathrm{n}=21)$, and $75 \%$ $(\mathrm{n}=56)$. Two replications of 'Wife' with microcuttings of 12 and 56 rooted at $100 \%$ and $95 \%$, respectively. According to our observations, the larger the microshoot, the better the rooting success and in vitro shoot multiplication potential.

We demonstrated that retipping using recently micropropagated hemp plants produces a sufficient number of liner plants for large-scale commercial production. Micropropagated plants that were recently acclimated to greenhouse conditions yielded $\approx 10$ retip cuttings during weeks 1 and 2 of the 10 -week propagation time course (Figs. 4 and 5 ). After the first 1 or 2 weeks, cutting productivity increased to a maximum of 50 cuttings per week (Fig. 5). For all three replications of retipping, cutting productivity remained high over the course of 10 weeks. Generally, $\geq 90 \%$ rooting success was achieved weekly, and rooting never decreased to less than $78 \%$. Over the course of 10 weeks, averages of $90.8 \%$

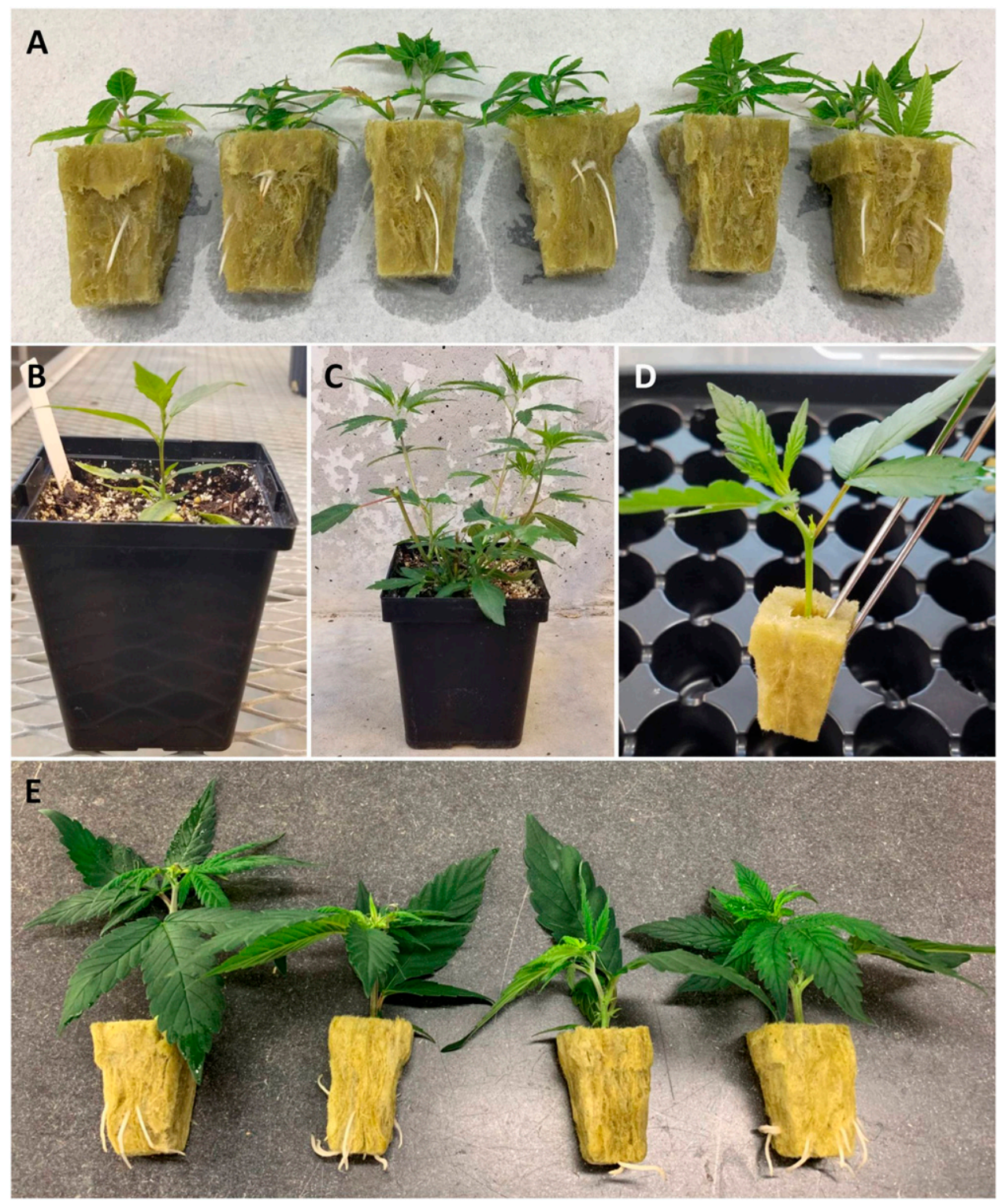

Fig. 4. Micropropagated and retip (cuttings of new shoots from recently micropropagated plants) hemp plantlets of 'Dinamed CBD' (A) 21 d after transfer to rockwool cubes ex vitro; (B) greenhouse-acclimated micropropagated plant $10 \mathrm{~d}$ after potting; (C) new shoot breaks on micropropagated stock plants after retipping; (D) retip cutting stuck in rockwool cube; and (E) rooted retip cuttings $21 \mathrm{~d}$ after sticking. 

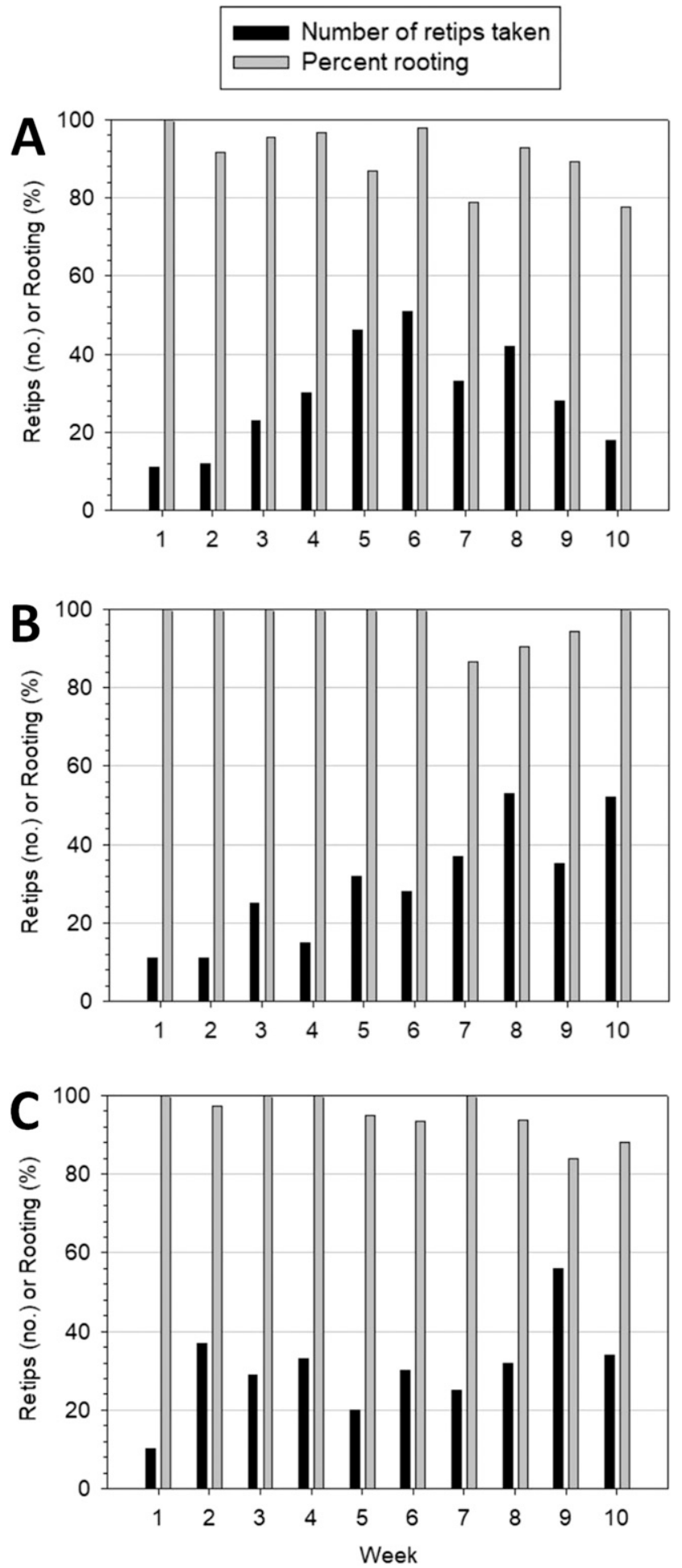

Fig. 5. Number of retips (cuttings of new shoots from recently micropropagated plants) taken per week from 10 micropropagated hemp stock plants and cutting percent rooting for (A) 'Dinamed CBD' initiated in July 2019; (B) 'Dinamed CBD' initiated in Aug. 2019; and (C) 'Wife' initiated in Apr. 2020.

and $96 \%$ rooting were achieved for 'Dinamed CBD' replication 1 and replication 2, respectively, and an average of $93.8 \%$ rooting was achieved for 'Wife'. Using traditional stem cuttings from mother plants, Caplan et al. (2017) reported maximum rooting success of $71 \%$. Rooting success varied from $35 \%$ to $100 \%$ for three distinct hemp cultivars propagated from stem cuttings (Campbell et al., 2019). The rooting ability of retip cuttings was steady over 10 weeks, and it is likely that strong rooting would have continued for several more weeks. Using 10 micropropagated plants that use less than $0.25 \mathrm{~m}^{2}$ of grow space, $\approx 300$ retip cuttings were generated. Using a conservative $90 \%$ rooting rate, this translated to 270 plants within 10 weeks.

Our propagation method using retipping of micropropagated hemp yields more liners than the traditional method using mother plants and stem cuttings. Mother plants grown in 10gal pots to provide cuttings for propagation occupy floor space of $\geq 1 \mathrm{~m}^{2}$. A large mother plant may provide 50 to 60 cuttings every 2 weeks and, under ideal circumstances, cuttings root at $80 \%$. This translates to 200 plants within 10 weeks from floor space of $1 \mathrm{~m}^{2}$. The same $1 \mathrm{~m}^{2}$ of floor space could hold 67 micropropagated plants that would produce nearly 1800 plants, which is nine-times the number of liners from traditional cutting mother plants. Furthermore, because of the small size of stock plants used for retipping, it is possible to have three sets of 67 stock plants stacked in a three-tier, shelved bench arrangement in $1 \mathrm{~m}^{2}$ of floor space. Such a three-tier growing system containing 201 plants would produce 5400 retip liners. Plants from retip cuttings have been observed to grow vigorously at a similar or faster rate than plants from traditional vegetative cuttings.

The retip micropropagation system described will generate nine-times more hemp liners for commercial production in the same grow space as traditional mother plants and stem cuttings. Furthermore, liner plants produced through retipping are clonal, uniform, disease-free, and vigorous. Our in vitro shoot initiation and multiplication methods demonstrate improved hemp micropropagation results. We have eliminated shoot hyperhydricity, enhanced culture growth, and extended the time during which in vitro cultures remain productive. Although our method uses some micropropagated plants, much of the process only requires conventional propagation facilities and labor. Retipping takes advantage of all the benefits of micropropagation 
while limiting the amount of tissue culture infrastructure that is needed by producers.

\section{Literature cited}

Bechtel, W. 2019. 41-Acre Kentucky greenhouse merges with hemp growing company. 9 Jan. 2021. <https://www. agweb.com/article/4l-acre-kentuckygreenhouse-merges-hemp-growingcompany>.

Brand, M.H. 1993. Agar and ammonium nitrate influence hyperhydricity, tissue nitrate and total nitrogen content of serviceberry (Amelanchier arborea) shoots in vitro. Plant Cell Tissue Organ Cult. 35:203-209, doi: 10.1007/bf00037271.

Campbell, L.G., S.G.U. Naraine, and J. Dusfresne. 2019. Phenotypic plasticity influences the success of clonal propagation in industrial pharmaceutical Cannabis sativa. PLoS One 14:e0213434, doi: 101371 /journal.pone.0213434.

Caplan, D., J. Stemeroff, M. Dixon, and Y. Zheng. 2017. Vegetative propagation of cannabis by stem cuttings: Effects of leaf number, cutting position, rooting hormone, and leaf tip removal. Can. J. Plant Sci. 98:1126-1132, doi: 10.1139/ cjps-2018-0038.

Cervantes, J. 2015. The encyclopedia of cannabis. Van Patten Publ., Vancouver, WA.

Hand, C., S. Maki, and B.M. Reed. 2014. Modeling optimal mineral nutrition for hazelnut micropropagation. Plant Cell Tissue Organ Cult. 119:411-425, doi: 10.1007/s11240-014-0544-y.

Hartmann, H.T., D.E. Kester, F.T. Davies, Jr., and R.L. Geneve. 2002. Hartmann \& Kester's plant propagation: Principles and practices. 7th ed. Prentice Hall, Upper Saddle River, NJ.

Ivanova, M. and J. Van Staden. 2009. Nitrogen source, concentration, and $\mathrm{NH}_{4} \mathrm{NO}_{3}$ ratio influence shoot regeneration and hyperhydricity in tissue cultured Alos polyphylla. Plant Cell Tissue Organ Cult. 99:167-174, doi: 10.1007/ s1 1240-009-9589-8.
Keith, V.M. and M.H. Brand. 1995. Influence of culture age, cytokinin level, and retipping on growth and incidence of brooming in micropropagated rhododendrons. J. Environ. Hort. 13:72-77.

Kevers, C., M. Coumans, M.F. CoumansGilles, and T.H. Caspar. 1984. Physiological and biochemical events leading to vitrification of plants cultured in vitro. Physiol. Plant. 61:69-74.

Lata, H., S. Chandra, I. Khan, and M.A. Elsohly. 2009. Thidiazuron-induced high frequency direct shoot organogenesis of Cannabis sativa L. In Vitro Cell. Dev. Biol. Plant 45:12-19, doi: 10.1007/ s11627-008-9167-5.

Lata, H., S. Chandra, N. Techen, I.A. Khan, and M.A. Elsohly. 2016. A protocol refinement using novel aromatic cytokinin meta-topolin and the assessment of eco-physiological, biochemical and genetic fidelity of micropropagated plants. J. Appl. Res. Med. Aromat. Plants 3:18-26, doi: 10.1016/j.jarmap.2015. 12.001 .

Majada, J.P., M.L. Centeno, I. Feito, B. Fernandez, and R. Sanchez-Tames. 1998. Stomatal and cuticular traits on carnation tissue culture under different ventilation conditions. Plant Growth Regulat. 25:113-121, doi: 10.1023/b:grow.0000009706.70078.1c.

Monthony, A.S., S.R. Page, M. Hesami, and A.M.P. Jones. 2021. The past, present and future of Cananbis sativa tissue culture. Plants 10:1-28, doi: 10.3390/ plants10010185.

Murashige, T. and F. Skoog. 1962. A revised medium for rapid growth and bio assays with tobacco tissue cultures. Physiol. Plant. 18:100-127.

Nairn, B.J., R.H. Furneaux, and T.T. Stevensen. 1995. Identification of an agar constituent responsible for hydric control in micropropagation of radiata pine. Plant Cell Tissue Organ Cult. 43:1-11, doi: $10.1007 / \mathrm{bf00042665.}$

Niedz, R.P., S.E. Hyndman, T.J. Evens, and A.A. Weathersbee. III. 2014. Mineral nutrition and in vitro growth of Gervera bybrida (Asteraceae). In Vitro Cell. Dev. Biol. Plant 50:458-470, doi: 10.1007/ s11627-014-9620-6.
Pence, V.C., L.R. Finke, and R.P. Niedz. 2020. Evaluating a DOE screen to reduce hyperhydricity in the threatened plant, Cycladenia humilis var. jonesii. In Vitro Cell. Dev. Biol. 56:215-229, doi: 10.1007/s1 1627-019-10038-y.

Poothong, S. and B.M. Reed. 2015. Increased $\mathrm{CaCl}_{2}, \mathrm{MgSO}_{4}$, and $\mathrm{KH}_{2} \mathrm{PO}_{4}$ improve the growth of micropropagated red raspberries. In Vitro Cell. Dev. Biol. Plant 51:648-658, doi: 10.1007/ s11627-015-9720-y.

Poothong, S., J. Morre, C.S. Maier, and B.M. Reed. 2017. Metabolic changes and improved growth in micropropagated red raspberry 'Indian Summer' are tied to improved mineral nutrition. In Vitro Cell. Dev. Biol. Plant 53:579-590, doi: 10.1007/s11627-017-9845-2.

Poothong, S., T. Khen, and O. Chumphukam. 2018. In vitro mineral nutrition for improving growth and multiplication of stevia. Agr. Nat. Resour. 52:477-483, doi: 10.1016/j.anres.2018.11.007.

Rosslee, J. 2020. The future of cannabis cloning - Tissue culture. 10 Dec. 2020. <https://www.plantcelltechnology . $\mathrm{com} /$ pct-blog/the-future-of-cannabiscloning-tissue-culture $/>$.

Small, E. 2015. Evolution and classification of Cannabis sativa (marijuana, hemp) in relation to human utilization. Bot. Rev. 81:189-294, doi: 10.1007/ s12229-015-9157-3.

Trevisan, F. and B.M.J. Mendes. 2005. Optimization of in vitro organogenesis in passion fruit (Passiflora edulis f. flavicarpa). Scientia Agricula 62:246-350, doi: 10.1590/S010390162005000400007 .

Wada, S., R.P. Niedz, J. DeNoma, and B.M. Reed. 2013. Mesos components $\left(\mathrm{CaCl}_{2}, \mathrm{MgSO}_{4}\right.$, and $\left.\mathrm{KH}_{2} \mathrm{PO}_{4}\right)$ are critical for improving pear micropropagation. In Vitro Cell. Dev. Biol. Plant 49:356365, doi: 10.1007/s1 1627-013-9508-x.

Wang, R., L.S. He, B. Xia, J.F. Tong, N. $\mathrm{Li}$, and F. Peng. 2009. A micropropagation system for cloning of hemp (Cannabis sativa L.) by shoot tip culture. Pak. J. Bot. 41:603-608. 